\begin{tabular}{ccc}
\hline UNIVERSITA & DEPARTMENT OF \\
DEGLISTUDI \\
DI TORINO
\end{tabular}

\title{
MONEY LAUNDERING AS A FINANCIAL SECTOR CRIME \\ A NEW APPROACH TO MEASUREMENT, WITH AN APPLICATION TO ITALY
}

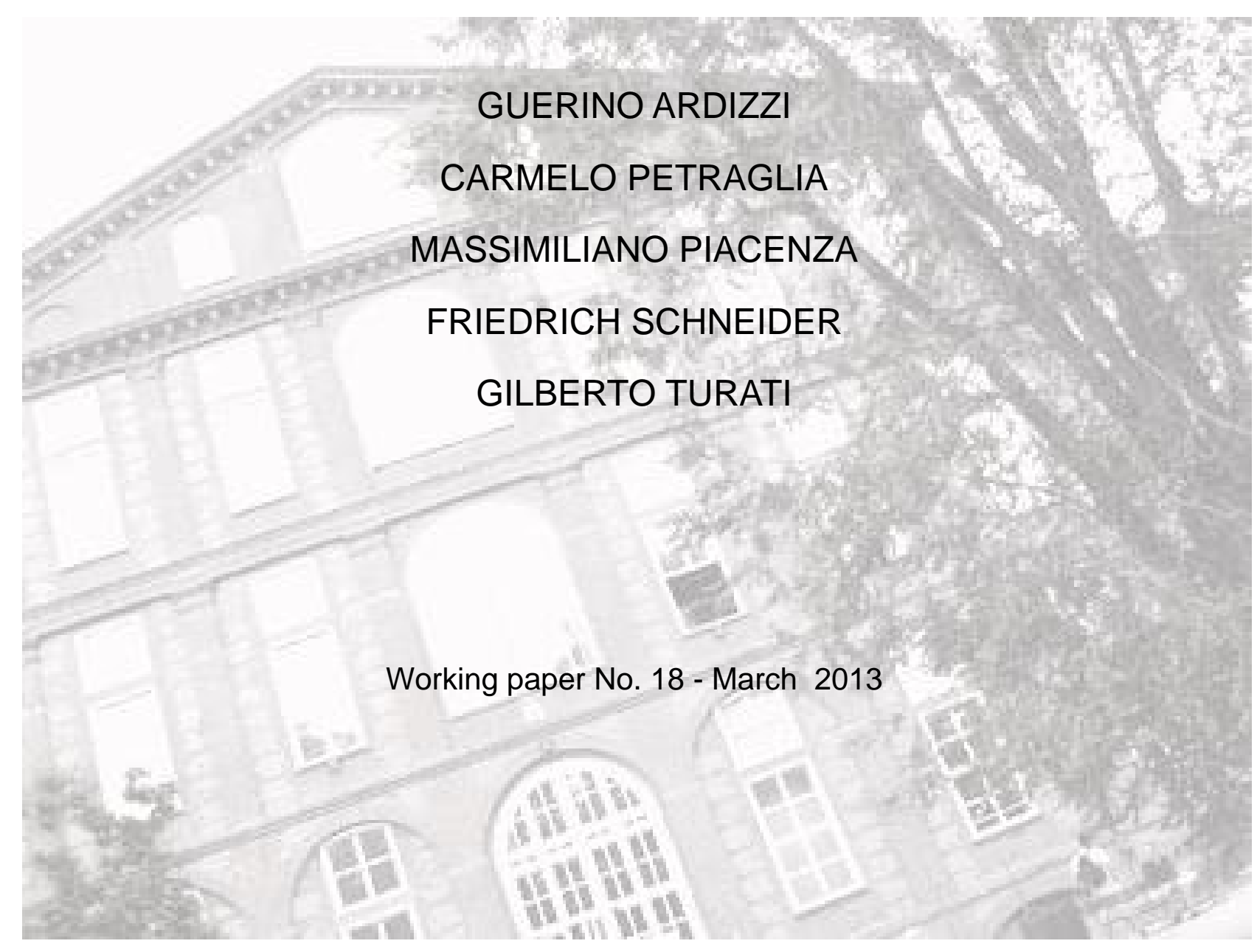




\title{
Money Laundering as a Financial Sector Crime \\ A New Approach to Measurement, with an Application to Italy*
}

\author{
Guerino ARDIZZI \\ (Bank of Italy, guerino.ardizzi@bancaditalia.it) \\ Carmelo PETRAGLIA \\ (University of Basilicata, carmelo.petraglia@unibas.it) \\ Massimiliano PIACENZA \\ (University of Torino, massimiliano.piacenza@econ.unito.it) \\ Friedrich SCHNEIDER \\ (Johannes Kepler University of Linz, Friedrich.Schneider@jku.at) \\ Gilberto TURATI \\ (University of Torino, gilberto.turati@econ.unito.it)
}

March 1st, 2013

\begin{abstract}
Anti-money laundering regulations have been centred on the "Know-Your-Customer" rule so far, overlooking the fact that criminal proceedings that need to be laundered are usually represented by cash. This is the first study aimed at providing an answer to the question of how much of cash deposited via an official financial institution can be traced back to criminal activities. The paper develops a new approach to measure money laundering and then proposes an application to Italy, a country where cash is still widely used in transactions and criminal activities generate significant proceeds to be laundered. In particular, we define a model of cash inflows on current accounts and proxy money laundering with two indicators for the diffusion of criminal activities related to both illegal trafficking and extortion, controlling also for structural (legal) motivations to deposit cash, as well as the need to conceal proceeds from tax evasion. Using a panel of 91 Italian provinces observed over the period 2005-2008, we find that the amount of cash laundered is sizable, around 7\% of GDP, $3 / 4$ of which is due to illegal trafficking, while $1 / 4$ is attributable to extortions. Furthermore, the incidence of "dirty money" coming from illegal trafficking is higher in the Centre-North than in the South, while the inverse is true for extortions. Results are useful to discuss policy initiatives to combat money laundering.
\end{abstract}

JEL classification: K42, H26, G28

Keywords: Money laundering, Shadow economy, Banking regulation

* We wish to thank Mario Gara (Financial Intelligence Unit, Bank of Italy) and seminar participants at the XXIV Conference of the Italian Public Economics Association for helpful comments. The usual disclaimers apply. 


\section{Introduction}

Financial sector crimes are defined - in a broad sense - as any non-violent crime involving a (regulated) financial institution which result in a financial loss because of fraud or embezzlement (e.g., IMF, 2001; FBI, 2011). Financial institutions can be involved in such crimes as victims, as perpetrators, or just as instrumentality. Check and credit card frauds are examples of crimes for which financial institutions are victims. The sale of fraudulent financial products is an example of crimes for which financial institutions are perpetrators. Money laundering is the most important example of the third type of crime. Money laundering is defined by the U.S. Department of Justice as "the process by which criminals conceal or disguise the proceeds of their crimes or convert those proceeds into goods and services. It allows criminals to infuse their illegal money into the stream of commerce, thus corrupting financial institutions and the money supply, thereby giving criminals unwarranted economic power" (FBI, 2011). According to estimates provided by the Financial Action Task Force (FATF) - an intergovernmental body created in 1989 by the G7 to fight money laundering and terrorism financing - criminal proceedings laundered via the international financial system could reach about $2 \%$ of global GDP (IMF, 2001), posing a serious problem to governments.

The standard approach followed by regulators to face the problem has been proposed by the FATF in its Forty Recommendations - which significantly overlap with the Basel Core Principle for Banking Supervision - and has been recognized by the Wolfsberg Group in a selfregulation initiative involving eleven large international banks. The cornerstone of the approach is the "Know-Your-Customer" (KYC) rule, i.e., the need for financial and banking systems to be transparent: every transaction within the system need to be traced to an identifiable individual (e.g., IMF, 2001). The KYC rule is, however, subject to severe limitations. Sharman (2010) suggests for instance the possibility to set up anonymous shell companies, which can then be used to set up anonymous bank accounts ${ }^{1}$. This is easier to be done in tax havens which offer corporate and banking secrecy (Hines, 2010). Most of the tax havens are indeed included also in the list of non-cooperative countries and territories (NCCT) by the FATF.

${ }^{1}$ Findley et al. (2012) show that "international rules that those forming shell companies must collect proof of customers" identity are ineffective". 
However, an important issue - which has been somewhat overlooked in regulation initiatives so far - is that criminal proceedings that need to be laundered are usually represented by cash. As is well known, cash is different from other payment instruments in that it guarantees anonymity: notes pass from hand to hand without being traceable, reducing the degree of transparency of the financial and banking systems (e.g., Payments Council, 2010). But despite this, and despite the costs of managing the cash cycle are high for banks (e.g., because they need to refill ATMs networks), cash is still largely used in the world economy. In Europe, for instance, the euro cash-in circulation has doubled since euro coins and notes became legal tender in 2002, even if this measure excludes the high-denomination banknotes that are most commonly hoarded (e.g., Capgemini and Royal Bank of Scotland, 2011).

How much of the cash deposited via a regulated financial institution can be traced back to criminal activities? In this paper we try - for the first time - to provide an answer to this important question, initially developing a new approach to measure money laundering, and then proposing an application to Italy, a country where cash is still widely used, non-cash payment methods are not well developed, criminal activities generate significant cash proceeds that needs to be laundered, but also the underground economy contribute to increase the demand for cash that is then fed back into the financial system (e.g., Ardizzi et al., 2013). The new methodology proposed here is based on the flows of cash pumped into the financial system, and will thus provide a (lower bound) estimate of the amount of money laundered at its very early stage. Still, this represents a significant improvement with respect to available estimates, which - instead of being based on econometric models using observed data - are almost exclusively derived from data generated by the calibration of theoretical models (e.g., Barone and Masciandaro, 2011, and Argentiero et al., 2008, for Italy).

The remainder of the paper is structured as follows. In Section 2 we define a new approach for measuring money laundering: we present our methodology - based on the specification of an econometric model of demand for cash deposits - and formulate testable hypotheses. In particular, we distinguish the "dirty money" component of the flows of cash deposited in current (bank and postal) accounts from the legal and the shadow economy proceeds, and then discuss the variables affecting each of these three components. In Section 3 we first discuss the estimates of the model controlling for alternative sources of the demand for cash deposits, and then provide estimates of the size of money laundering at the national level, and 
split them up to each Italian province. We also test the robustness of our findings both to a different specification of the econometric model, which explicitly accounts for unobserved heterogeneity across provinces, and to the exclusion from the sample of border provinces where illegal proceeds could be laundered using foreign banks, a practice that can clearly bias our estimates of the size of money laundering. Finally, after a brief summary, some policy implications for contrasting money laundering are discussed in Section 4.

\section{Estimating money laundering via flows of cash deposited on current accounts: methodology and theoretical insights}

\subsection{Cash deposits are observable, money laundering is not}

From a theoretical point of view money laundering is a relatively easy-to-define concept: it is a criminal offense which originates from other underlying criminal activities, that amplifies in a cumulative way the impact of crime on both regular and irregular economies. More specifically, money laundering is the process by which income stemming from crime is "cleaned up" through the legal channel (e.g., via bank transactions); once "cleaned up", money can then be reinvested in legal activities. Following Schneider and Windischbauer (2008), this process can be summarized in three main stages:

a) PLACEMENT: «ill-gotten gains from punishable pre-actions are infiltrated into the financial system; at this junction there is an increased risk of being revealed»;

b) LAYERING: «criminals attempt to conceal the source of illegal income through a great deal of transactions by moving around black money. Transaction intensity and transaction speed are increased withal (multiple transfer and transaction); electronic payment systems plus diverging jurisdiction and inefficient cooperation of criminal prosecution often simplify/facilitate the layering processes as well»;

c) INTEGRATION: «infiltration of transformed and transferred capital into formal economy by means of financial investments (specific deposits, stocks) or property (direct investment in real estates and companies) is primarily completed in countries promising extraordinary short odds».

While the concept is relatively easy to define theoretically, the size and the empirical relevance of money laundering is difficult to estimate, since the illicit money pumped into the financial system cannot be observed directly. Exploring the scale and the impact on the 
financial system of illicit funds is the goal of a rather new field of research, the economics of money laundering. ${ }^{2}$ Both Schneider and Windischbauer (2008) and Barone and Masciandaro (2011) point out that the pioneering efforts to estimate money laundering provide results that are scientifically doubtful, since they seem to exploit "tacit knowledge" and "feelings" that make them not replicable and unproven (e.g., Tanzi, 1997; Walker, 1999). Moreover, there are two important limitations in the current literature: first, the type of predicate crimes (i.e., the crimes whose proceeds are laundered) considered to assess the size of money laundering has been limited almost exclusively to narcotics trafficking (e.g., Barone and Masciandaro, 2011; UNODC, 2011), while criminal organizations actually engage in a number of other crimes. Second, and more important, most of the recent available studies consider data generated from the calibration of theoretical models instead of actual data, which often muddle up the laundering activities with the shadow economy, two linked but different phenomena (e.g., Argentiero et al., 2008).

The approach proposed here improves the accuracy of current estimates, starting from a very simple idea, which basically extends the well-known Currency Demand Approach used to estimate the size of shadow economy, another phenomenon that cannot be observed directly. Money laundering is unobservable, but other variables necessarily related to money laundering indeed are. And, among these, cash deposited via a regulated financial institution is probably the most important. Hence, since cash in-flows are - at least partly - attributable to criminal proceeds that need to be laundered, what one is required to do to estimate the size of money laundering is to separate illegal proceeds from criminal activities from other determinants of in-flows, including legal as well as illegal profits from tax evasion. In other words, one needs to run a decomposition exercise, and identify the share of cash in-flows attributable to each of their determinants.

Let INCASH be the ratio of the value of total cash in-flows on current (bank and postal) accounts to the value of total non-cash in-flows credited to current (bank and postal) accounts. This ratio basically represents the amount of non-traceable funds per euro of traceable ones. In order to disentangle the "dirty money" component of these cash in-flows, one needs to identify proxy variables for the amount of cash originated by criminal activities (call these $Z$ ), and to control for alternative sources of cash in-flows linked to both legal activities and

2 Argentiero et al. (2008), Barone and Masciandaro (2011), Masciandaro et al. (2007), Schneider (2010) and Unger $(2007,2009)$ all provide surveys of the available literature. 
proceeds from the underground economy (call these control variables $X$ ). One can then assume a linear relationship between $I N C A S H, X$ and $Z$, with conditionally independent errors $E\left(\varepsilon_{i t} \mid Z_{i t}, X_{i t}\right)=0$, and run a regression model like the following Equation [1]:

$$
I N C A S H_{i t}=\alpha_{0}+\sum_{k} \alpha_{k} X_{i t}+\sum_{h} \alpha_{h} Z_{i t}+\varepsilon_{i t}
$$

from which to estimate the size of INCASH due to factors $Z$. The main issue is therefore to identify variables to be included in $X$ and $Z$, which is what we do next.

Before moving further, notice that, considering cash in-flows on current (bank and postal) accounts, our estimation strategy will cover only step (a) - the PLACEMENT - in the process of money laundering. Moreover, notice that our estimates of "dirty money" can be interpreted as a lower bound of the whole volume of money laundered within a country. In fact, illegal money directly converted into other assets (such as real estates, diamonds, gold and vehicles) are not considered here, since the focus is specifically on the role played by regulated financial institutions. Finally, we do not consider illegal cash brought to an alternative remittance provider for the placement outside of the banking system (e.g., "money-transfers" agents). However, notice that since bank money is essential to transform capital into profitable investments in the global formal economy, it is reasonable to assume that a relevant share of illegal funds placed outside the banking system will be subsequently deposited in cash on a bank account.

\subsection{Proxying the "dirty money" component of the demand for cash deposits}

Proxying the "dirty money" component of the cash in-flows requires to preliminary define the criminal activities that generate illegal profits to be cleaned up, and then to select the variables aimed at capturing their diffusion at the provincial level. As for the definition of criminal activities, we rely on the distinction originally proposed by Block (1980) - well established in the literature on organized crime - between "enterprise syndicate" and "power syndicate". The former concept refers to criminal groups running illegal economic activities such as drug trafficking, smuggling, and prostitution, while the latter refers to organized crime structures involved in the social, economic and military control of a specific territory. Such a distinction is crucial for instance in Italy, where organized crime has "headquarters" predominantly localized in the South, while the "retail markets" for goods and services (such 
as drug and prostitution) prove to be more lucrative in the richest Centre-North regions of the country (Ardizzi et al., 2013).

The relative presence of "power syndicate" (POWER) at the provincial level is measured by the number of detected crimes from extortions within the province (normalized by its sample mean value). The choice to focus on extortions is motivated by the fact that this is the main way through which criminal organizations gain the control of territory at the local level. For instance, Gambetta (1993) points out that the Sicilian Mafia uses extortion as «an industry which produces, promotes, and sells private protection», and Alexeev et al. (2004) argue that the payments extorted by organized crime can be viewed as additional "taxation" imposed to firms. The request for protection is made regardless of the will of citizens, and using Gambetta's words «whether one wants or not, one gets it and is required to pay for it». The same argument applies to the other Italian regions traditionally dominated by powerful criminal organizations, such as the Camorra in Campania, the "Ndrangheta in Calabria, and the Sacra Corona Unita in Puglia ${ }^{3}$.

The relative diffusion of "enterprise syndicate" (ENTERPRISE) in a province is measured by the number of detected crimes from drug dealing, prostitution and receiving stolen within the province (normalized by its sample mean value). Such a proxy is able to account for those illegal services provided on the basis of a mutual agreement, as well as those imposed with the use of violence. Indeed, drug- and prostitution-related offenses - in line with the OECD (2002) definition of illegal economy - imply an exchange between a seller and a buyer based on a mutual agreement. On other hand, receiving stolen are based on the use of violence made to persons or properties, and then imply "payments" which do not follow an "agreement" between the thief, for instance, and the victim. We believe that accounting for both types of offences is important in our model since both activities generate proceeds to be cleaned up. Both the variables ENTERPRISE and POWER are weighted by a GDP concentration index. Such a standardization allows us to better compare provinces characterized by remarkable differences in the level of socio-economic development and, perhaps, in the effort of crime detection and contrasting, thus avoiding attaching automatically higher levels of crime (and money laundering) to provinces with a number of detected offences above the sample mean. Both indicators for the diffusion of criminal activities are expected to show

\footnotetext{
${ }^{3}$ A recent and detailed study on extortion activities in the EU member states is provided in Transcrime (2008).
} 
positive correlations with cash in-flows. Thus, we put forward our first and main testable hypothesis:

H1: The higher the diffusion of crime, the larger is money laundering, hence the higher the demand for cash deposits, ceteris paribus.

\subsection{The role of legal motivations and the proceeds from the underground economy}

In order to control for the determinants of INCASH other than money laundering, our model includes a set of variables expected to capture the legal motivations of cash deposit demand, as well as its component linked to proceeds from the underground economy, i.e., proceeds from legal activities which are however hidden to Tax Authority in order to evade taxes. As for the legal motivations, we introduce the following controls: the degree of local socioeconomic development; the interest rate on bank deposits; the diffusion of electronic payment instruments in commercial transactions. As suggested by several studies on shadow economy (e.g., Schneider and Enste, 2000; Schneider, 2011), per capita GDP has a negative expected impact on the use of cash: the higher the average living standard, the lower is the use of cash for payments, thus the lower should be the demand for cash deposits because the volume of currency circulating at the local level is lower. The average income is highly correlated with education level (both general education and "financial literacy"), and more education usually leads to a lower use of cash, since more educated individuals show greater confidence in alternative payment instruments (World Bank, 2005). Our first measure of socio-economic development is per capita provincial GDP (YPC) and the related hypothesis to be tested is the following:

H2: The higher the average per capita income of a province, the lower is the demand for cash deposits, ceteris paribus.

We also consider the rate of unemployment at the provincial level (URATE) as a second possible indicator for the level of economic development. In particular, to some extent this variable reflects differences in income distribution (see, e.g., Brandolini et al., 2004), thus in educational levels, and is expected to exert a positive impact on the use of cash for payments, thus on the demand for cash deposits: for a given average value of per capita GDP, a higher unemployment rate corresponds to an income distribution more concentrated in high-income 
classes, with a larger share of low-income (and poorly educated) people relying on the use of cash for their payments. We formulate then the following hypothesis:

H3: The higher the unemployment rate of a province, the higher is the demand for cash deposits, ceteris paribus.

A further control is needed in order to capture the variability across provinces of the average attitude towards the use of cash in transactions as an alternative to electronic means of payment. Several studies (e.g., Drehmann and Goodhart, 2000; Goodhart and Krueger, 2001; Schneider, 2009) emphasize the importance of the technology of payments, with a particular reference to the supply of electronic instruments. In line with this literature, we account for available technology of payments at the provincial level by including the variable ELECTRO among the legal determinants of INCASH. This variable measures the ratio of the value of transactions settled by electronic payments to the total number of current accounts. A higher share of electronic transactions implies a lower general attitude of individuals towards the use of cash and, as a consequence, a lower demand for cash deposits. Thus, the expected sign of the ELECTRO coefficient is negative.

H4: The higher the diffusion of electronic payments in commercial transactions, the lower is the demand for cash deposits, ceteris paribus.

Finally, we consider the interest rate on current deposits $(I N T)$ as a possible determinant of the legal component of INCASH. Based on standard economic theory, the interest rate on deposits is expected to have a positive effect on INCASH, via its role of opportunity cost of holding non-interest bearing currency. Thus, due to the usual "speculative" motive, the expected sign of $I N T$ should be positive. However, there exist at least four reasons why this could not be the case. First, INCASH is defined by a share, which implies that a higher interest rate could in principle impact proportionally both on its denominator and numerator, leading to a null overall effect. Second, our model deals with cash in-flows rather than stock of deposits, which implies an ambiguous effect of the interest rate ${ }^{4}$. Furthermore, the years covered by our estimations have been characterized by very low interest rates, which is likely to have strongly mitigated the speculative motive (ECB, 2008). Finally, we notice that most

\footnotetext{
${ }^{4}$ For a more detailed discussion on recent trends of both flow and stock monetary aggregates in Italy, see Ardizzi et al. (2013).
} 
recent developments in innovative banking (i.e., internet banking) - which increased the supply of products characterized by lower operational costs and higher interest rates with respect to traditional banking - might even bring about a negative relationship between INT and cash deposits. Given these considerations, the expected sign of the INT coefficient is a priori unclear and we do not formulate any hypothesis on its sign.

The indicators used for controlling cash in-flows linked to proceeds from the underground economy at the provincial level are the importance of particular productive sectors in local economies, and the diffusion of tax frauds in sales by commercial retailers. The composition of local production by economic sectors has been found to significantly affect the size of the shadow economy (e.g., Johnson et al., 2000). Employment shares in agriculture (EMP_AGR) and the construction industry $\left(E M P \_C O N\right)$ are variables traditionally used as proxies for the evasion of income tax and social security contributions, being these the typical sectors with a higher presence of irregular workers (e.g., Torgler and Schneider, 2009; Capasso and Jappelli, 2011). As for Italy, according to the recent estimates provided by ISTAT (2010), irregular workers were $12.2 \%$ of total employment in 2009 , and the phenomenon was particularly concentrated precisely in the agricultural sector $(24.5 \%$ of irregular workers) and the construction sector $(10.5 \%)$. Thus, we formulate the following hypothesis:

H5: The larger the employment in the agricultural and the construction sectors, the higher is the number of irregular workers and the demand for cash deposits due to proceeds from the underground economy, ceteris paribus.

Finally, we include in our model a variable controlling for irregularities detected by the Guardia di Finanza (the Italian Tax Police) through tax inspections at retailers. COMM_FRAUDS is given by the ratio of the number of positive audits on cash registers and tax receipts to the number of existing POS in the province. The standardization for the number of POS is made necessary by the high variability in the presence of POS across provinces, which is likely to affect the opportunity to evade (lower where the number of POS is higher, see Ardizzi et al., 2013). This ratio is weighted by a GDP concentration index for the same reason discussed above for crime variables. Our working hypothesis is then:

H6: The higher the diffusion of commercial tax frauds, the higher is the demand for cash deposits due to shadow economic proceeds, ceteris paribus. 


\subsection{Assessing the size of money laundering}

Equation [2] provides the complete model of the demand for cash deposits to be estimated, which indentify cash in-flows to be laundered, controlling for the role of legal (or structural) motivations and the proceeds from the shadow economy:

$$
\begin{aligned}
& \text { INCASH }_{i t}=\alpha_{0}+\alpha_{1} \text { YPC }_{i t}+\alpha_{2} \text { URATE }_{i t}+\alpha_{3} \text { ELECTRO }_{i t}+\alpha_{4} \text { INT }_{i t}+\alpha_{5} \text { EMP }_{-} \text {AGR }_{i t}+ \\
& \alpha_{6} \text { EMP_CON }_{i t}+\alpha_{7} \text { COMM_FRAUDS }_{i t}+\alpha_{8} \text { ENTERPRISE }_{i t}+\alpha_{9} \text { POWER }_{i t}+\varepsilon_{i t}
\end{aligned}
$$

In analogy with the reinterpretation of the Currency Demand Approach proposed in Ardizzi et al. (2013) to estimate the magnitude of the underground economy, the size of money laundering is assessed here by estimating the "excess demand" for cash deposits unexplained by structural factors and business activities carried out in the underground sector. ${ }^{5}$ This "excess demand" is obtained as the difference between the fitted values of INCASH from the full model [2] and the predicted values obtained from a restricted version of Equation [2], where the coefficients of ENTERPRISE and POWER are set equal to zero. To evaluate separately the size of the two components of "dirty money", we then proceed in a similar manner, by imposing alternatively the restrictions $\alpha_{8}=0$ and $\alpha_{9}=0$, and calculating the excess demand for cash deposits due to criminal activities linked to illegal traffics and extortions, respectively. Given our definition of INCASH, money laundering estimates obtained with this procedure are expressed in relation to total deposits generated by instruments other than cash. Thus, in order to have measures comparable with those obtained in previous studies, we need to rescale our results and express them in terms of provincial GDP.

In the light of the above discussion about the greater diffusion of POWER in the (relatively poorer) Southern regions, we expect to find a higher incidence of this component of money laundering in the South. On the other hand, given the ability of criminal organizations to "export" illegal traffics in the richest areas of the country, where the demand for "goods and services" such as drug and prostitution is presumably higher, we expect to find a larger size of ENTERPRISE in the Centre-North. We then formulate this last hypothesis:

\footnotetext{
${ }^{5}$ Notice that, as remarked in Ardizzi et al. (2013), this reinterpretation of the CDA originally suggested by Tanzi $(1980,1983)$ reduces the methodology to a decomposition exercise in the spirit of, e.g., Wagstaff et al. (2003), hence avoiding problems of causality in the relationships among our dependent variable and the demand factors included in model [1]. In this perspective, all our testable hypotheses H1-H6 discussed above should not be read as causal effects but as simple correlations between INCASH and each regressor.
} 
H7: The incidence of money laundering component due to ENTERPRISE is relatively higher in the Centre-North, while the component due to POWER is relatively higher in the South.

\section{Econometric analysis}

\subsection{Data and estimation technique}

The model of the demand for cash deposits described by Equation [2] is estimated using a panel of 91 Italian provinces observed over the period 2005-2008. The units included in the final dataset represent about $90 \%$ of all the Italian provinces (103), and are those for which complete information were available for all the variables in Equation [1]. The Appendix reports the definition and descriptive statistics (for the whole sample, as well as for the two macro-areas, Centre-North and South, separately) and information about the different data sources (see Tables A1 and A2).

As for the estimation technique, given the panel structure of our data and the marked heterogeneity across units (as highlighted by the prevalence of the between component of standard deviation for all the variables excepting $I N T$, see Table A2), we preliminary check for the presence of heteroskedasticity, contemporaneous cross-sectional correlation and autocorrelation in the residuals. Ignoring heterogeneity and possible correlation of regression disturbances over time and between subjects can lead to biased statistical inference (e.g., Cameron and Trivedi, 2005). However, while most recent studies provide heteroskedasticand autocorrelation consistent standard error, cross-sectional or "spatial" dependence in the residuals is still often ignored, thus imposing an artificial and potentially biasing constraint on empirical models. Indeed, relying on proper statistical tests, we found that all the three problems are present in the error structure of our data ${ }^{6}$. Therefore, in order to adjust the standard errors appropriately, we perform a Prais-Winsten regression with Panel-Corrected Standard Errors (PCSE). In particular, we specify that, within groups, there is first-order autocorrelation and that the coefficient of the $\operatorname{AR}(1)$ process is specific to each group. ${ }^{7}$

\footnotetext{
${ }^{6}$ Specifically, we used the Wooldridge (2002) test for autocorrelation in panel data, the Greene (2000) test for groupwise heteroskedasticity, and the Pesaran (2004) test for cross-sectional dependence in panel data. All the results ara available on request from the authors.

${ }^{7}$ More technical details on this estimator are discussed in Hoechle (2007) and in the original contributions by Prais and Winsten (1954) - as for the problem of serially correlated residuals - and by Beck and Katz (1995) - as for the problem of heteroskedastic and contemporaneously cross-sectionally correlated residuals.
} 
Table 1: Estimates of cash deposit demand [1]: 91 Italian provinces, 2005-2008 (PraisWinsten regression with Panel-Corrected Standard Errors)

\begin{tabular}{|c|c|c|c|}
\hline Regressors $^{a}$ & Model 1 & Model 2 & Model 3 \\
\hline \multicolumn{4}{|c|}{ Money laundering component ${ }^{b}$} \\
\hline ENTERPRISE & $0.0312^{* * *}$ & $0.0272 * * *$ & $0.0268 * * *$ \\
\hline$[\mathrm{H} 1]$ & $(3.34)$ & $(2.52)$ & $(2.72)$ \\
\hline POWER & $0.0121^{* * *}$ & $0.0143^{* * *}$ & $0.0088^{*}$ \\
\hline$[\mathrm{H} 1]$ & $(2.49)$ & $(2.92)$ & $(1.83)$ \\
\hline \multicolumn{4}{|c|}{ Structural (legal)component ${ }^{\text {b }}$} \\
\hline$Y P C$ & $-0.0067 * * *$ & - & $-0.0044 * * *$ \\
\hline$[\mathrm{H} 2]$ & $(-5.03)$ & - & $(-3.06)$ \\
\hline$U R A T E$ & - & $0.6542 * * *$ & $0.3836 * * *$ \\
\hline [H3] & - & $(6.87)$ & $(2.62)$ \\
\hline ELECTRO & $-0.0012 * * *$ & $-0.0021 * * *$ & $-0.0015^{* * *}$ \\
\hline$[\mathrm{H} 4]$ & $(-3.56)$ & $(-8.98)$ & $(-5.92)$ \\
\hline \multirow[t]{2}{*}{$I N T$} & 0.0006 & $-0.010 * * *$ & -0.0019 \\
\hline & $(0.20)$ & $(-7.71)$ & $(-0.73)$ \\
\hline \multicolumn{4}{|c|}{ Shadow economy component ${ }^{b}$} \\
\hline$E M P \_A G R$ & $0.5658^{* * *}$ & $0.6080^{* * *}$ & $0.5104 * * *$ \\
\hline$[\mathrm{H} 5]$ & $(7.73)$ & $(7.55)$ & $(4.97)$ \\
\hline$E M P \_C O N$ & $0.3588 * * *$ & $0.4519 * * *$ & $0.3320 * * *$ \\
\hline [H5] & $(3.01)$ & $(3.00)$ & $(2.24)$ \\
\hline COMM_FRAUDS & $0.0479 * * *$ & $0.0763 * * *$ & $0.0605 * * *$ \\
\hline$[\mathrm{H} 6]$ & $(3.58)$ & $(8.18)$ & $(5.21)$ \\
\hline Constant & $\begin{array}{c}0.2107^{* * *} \\
(4.47) \\
\end{array}$ & $\begin{array}{c}0.0054 \\
(0.46) \\
\end{array}$ & $\begin{array}{c}0.1405^{* * *} \\
(2.63) \\
\end{array}$ \\
\hline Observations & 364 & 364 & 364 \\
\hline Wald statistic $\left(\chi^{2}\right)$ & $1590.86^{* * *}$ & $3658.13^{* * *}$ & $5004.28 * * *$ \\
\hline $\mathbf{R}^{2}$ & 0.92 & 0.91 & 0.92 \\
\hline
\end{tabular}

a Dependent variable: $I N C A S H=$ value of total cash in-payments on current accounts normalized to the value of total non-cash payments credited to current accounts; z-statistics in round brackets. b Theoretical hypothesis to which each regressor refers in squared brackets.

$* * *, * *, *$ : statistically significant at $1 \%, 5 \%, 10 \%$.

\subsection{Estimates of the demand for cash deposits}

Table 1 reports parameter estimates of Equation [2] according to three different specifications, where only YPC (Model 1), or URATE (Model 2), or both (Model 3) are included as control variables for the demand of cash deposits linked to the degree of socio-economic development. All the models perform quite well in terms of fit (the Wald statistic is always significant at 
the $1 \%$ level, and the $R^{2}$ is above 0.90 ) and show coefficients that are statistically significant and with signs consistent with our theoretical hypotheses H1-H6. ${ }^{8}$

More precisely, our results confirm that the demand for cash deposits can be decomposed into three types of drivers:

(1) a money laundering component: both the diffusion of illegal traffics (ENTERPRISE) and of extortion activities (POWER) prove to be positively associated to the relative size of cash in-flows [H1];

(2) a structural (legal) component: the average per capita income (YPC) and the diffusion of electronic payments $(E L E C T R O)$ are negatively correlated with cash in-flows [H2-H4], while the unemployment rate (URATE) shows a positive correlation [H3];

(3) a shadow economy component: both the two proxies for the diffusion of irregular workers $\left(E M P \_A G R\right.$ and $\left.E M P \_C O N\right)$ and the variable controlling for the presence of commercial tax frauds (COMM_FRAUDS) are positively associated with cash in-flows [H5-H6].

It is worth noticing that both indicators characterizing the local economy remain highly significant when used jointly (Model 3). This supports our argument that the unemployment rate captures an additional (distributional) dimension of socio-economic development besides the average per capita income, which helps better control for the legal motivations of the demand for cash deposits 9 .

An interesting finding is highlighted by Table A3 and Figure A1 in the Appendix, which report the average simulated contribution of each variable to the observed demand for cash deposits (expressed in percentage of GDP and normalized to 100), by referring to the most complete specification of Equation [2] (Model 3). The major (negative) role is played by the level of per capita GDP, while all the other regressors account for a much lower share of the demand for cash deposits. The predicted contributions also points to sensible differences across macro-areas. In particular, the incidence of $Y P C$ decreases (in absolute value) from 160 in the Centre-North to only 34 in the South, becoming relatively more close to the share of URATE (19), which is unsurprising given the greater relevance of unemployment in southern regions. Furthermore, in accordance with our hypothesis H7, the ENTERPRISE

\footnotetext{
${ }^{8}$ The only exception is the interest rate on bank deposits (INT), which shows no significant correlation or a negative correlation with cash in-flows. The likely motivations for this evidence have been discussed in Section 2.3 .

${ }^{9}$ On the joint use of the two variables, see also Buehn and Schneider (2012).
} 
component of criminal activities shows a much higher incidence in the Centre-North than in the South (26 vs. 12), while the inverse is observed for the share of POWER, although with a less marked gap (6 vs. 7).

Table 2: Size of money laundering as \% of GDP (mean 2005-2008) - PCSE estimates

\begin{tabular}{|c|c|c|c|c|c|c|}
\hline \multirow[b]{2}{*}{ Model 1} & \multicolumn{3}{|c|}{91 provinces a } & \multicolumn{3}{|c|}{83 provinces $^{b}$} \\
\hline & ITALY & $\begin{array}{c}\text { CENTRE- } \\
\text { NORTH }\end{array}$ & SOUTH & ITALY & $\begin{array}{c}\text { CENTRE- } \\
\text { NORTH }\end{array}$ & SOUTH \\
\hline TOTAL & $8.0 \%$ & $8.6 \%$ & $6.9 \%$ & $6.3 \%$ & $6.2 \%$ & $6.4 \%$ \\
\hline ENTERPRISE & $5.8 \%$ & $6.7 \%$ & $3.9 \%$ & $4.4 \%$ & $4.7 \%$ & $3.6 \%$ \\
\hline POWER & $2.2 \%$ & $1.9 \%$ & $3.0 \%$ & $1.9 \%$ & $1.5 \%$ & $2.8 \%$ \\
\hline Obs. & 364 & 256 & 108 & 332 & 228 & 104 \\
\hline \multirow[b]{2}{*}{ Model 2} & \multicolumn{3}{|c|}{91 provinces a } & \multicolumn{3}{|c|}{83 provinces $^{b}$} \\
\hline & ITALY & $\begin{array}{l}\text { CENTRE- } \\
\text { NORTH }\end{array}$ & SOUTH & ITALY & $\begin{array}{c}\text { CENTRE- } \\
\text { NORTH }\end{array}$ & SOUTH \\
\hline TOTAL & $7.7 \%$ & $8.0 \%$ & $6.9 \%$ & $6.0 \%$ & $5.9 \%$ & $6.5 \%$ \\
\hline ENTERPRISE & $5.1 \%$ & $5.8 \%$ & $3.4 \%$ & $3.8 \%$ & $4.1 \%$ & $3.2 \%$ \\
\hline POWER & $2.6 \%$ & $2.2 \%$ & $3.5 \%$ & $2.2 \%$ & $1.8 \%$ & $3.3 \%$ \\
\hline Obs. & 364 & 256 & 108 & 332 & 228 & 104 \\
\hline \multirow[b]{2}{*}{ Model 3} & \multicolumn{3}{|c|}{91 provinces $^{\text {a }}$} & \multicolumn{3}{|c|}{83 provinces ${ }^{b}$} \\
\hline & ITALY & $\begin{array}{c}\text { CENTRE- } \\
\text { NORTH }\end{array}$ & SOUTH & ITALY & $\begin{array}{c}\text { CENTRE- } \\
\text { NORTH }\end{array}$ & SOUTH \\
\hline TOTAL & $6.6 \%$ & $7.1 \%$ & $5.4 \%$ & $5.1 \%$ & $5.1 \%$ & $5.1 \%$ \\
\hline ENTERPRISE & $5.0 \%$ & $5.7 \%$ & $3.3 \%$ & $3.7 \%$ & $4.0 \%$ & $3.1 \%$ \\
\hline POWER & $1.6 \%$ & $1.4 \%$ & $2.1 \%$ & $1.4 \%$ & $1.1 \%$ & $2.0 \%$ \\
\hline Obs. & 364 & 256 & 108 & 332 & 228 & 104 \\
\hline
\end{tabular}

a Average values computed using the whole set of money laundering estimates related to the balanced panel of 91 Italian provinces.

b Before computing average values, we discarded all the provinces showing an outlier estimate of the POWER and/or the ENTERPRISE component in at least one year of the observed period. The 8 outliers were identified using the Hadi $(1992,1994)$ method and mostly correspond to the provinces of the biggest towns in Centre-North Italy. 


\subsection{Estimating the size of money laundering}

The size of money laundering for each province in each year has been assessed relying on the three model specifications discussed above, computing separate measures for the ENTERPRISE and POWER components. Table 2 shows the average values - for Italy and for the two sub-samples of provinces located in the Centre-North and in the South - obtained using the whole set of money laundering estimates for the 91 provinces. Averages are also computed dropping 8 outlier provinces identified applying the Hadi $(1992,1994)$ method with respect to the two components jointly considered. Notice that outliers mostly correspond to the provinces with the biggest (and the richest) towns in the Centre-North - like Rome, Milan and Turin - and are mainly driven by the ENTERPRISE component, thus confirming the polarization of illegal trafficking in the areas of the country where the "retail markets" for goods and services such as drug, prostitution and receiving stolen are more lucrative (Ardizzi et al., 2013).

Several interesting results emerge looking at Table 2. First, the estimated size of total money laundering ranges from $6.6 \%$ of GDP with Model 3 to around $8 \%$ when using the restricted specifications of Equation [2] that include only one indicator for the degree of socio-economic development (YPC in Model 1 and URATE in Model 2). This evidence points out that not accounting for the different features of the local economies (i.e., average per capita income and its distribution across the population), one could mistakenly attribute to money laundering a part of cash in-flows linked to other motivations.

Second, in all models the national level estimates highlight that the major role in determining the relative size of money laundering is played by the ENTERPRISE component of criminal activities. In particular, according to the most complete specification of cash deposit demand (Model 3), about 3/4 of dirty money is attributable to illegal trafficking (5\%), while $1 / 4$ is due to POWER (1.6\%). However, looking at the estimates disaggregated at the macro-area level, there are remarkable differences between Centre-Northern and Southern provinces in terms of both the whole size of money laundering and the relative contributions of the two types of criminal activities. More precisely, the share of dirty money on GDP is $7.1 \%$ in the CentreNorth against 5.4\% in the South; as for the incidence of ENTERPRISE and POWER, the former in Centre-Northern provinces is about 1.7 times higher than in Southern ones $(5.7 \%$ vs. $3.3 \%$ ), while the inverse is true for money laundering coming from extortion activities, for 
which the share in the South is 1.5 times the value of the Centre-North $(2.1 \%$ vs. $1.4 \%)$. This provides further support to our argument in hypothesis $\mathrm{H} 7$ of a greater incidence of illegal trafficking proceeds in the richest areas of the countries and of proceeds from the direct control of the territory through military power in the regions traditionally dominated by the big criminal organizations, such as Mafia, Camorra, 'Ndrangheta, and Sacra Corona Unita. This picture emerges also from Figure 1, which shows the geographical distribution of the size of money laundering by province, considering the aggregate TOTAL size and distinguishing ENTERPRISE from POWER.

Figure 1: Geographical distribution of money laundering size as a \% of GDP by province (PCSE estimates on 91 Italian provinces, mean 2005-2008 - Model 3)

\section{ENTERPRISE}

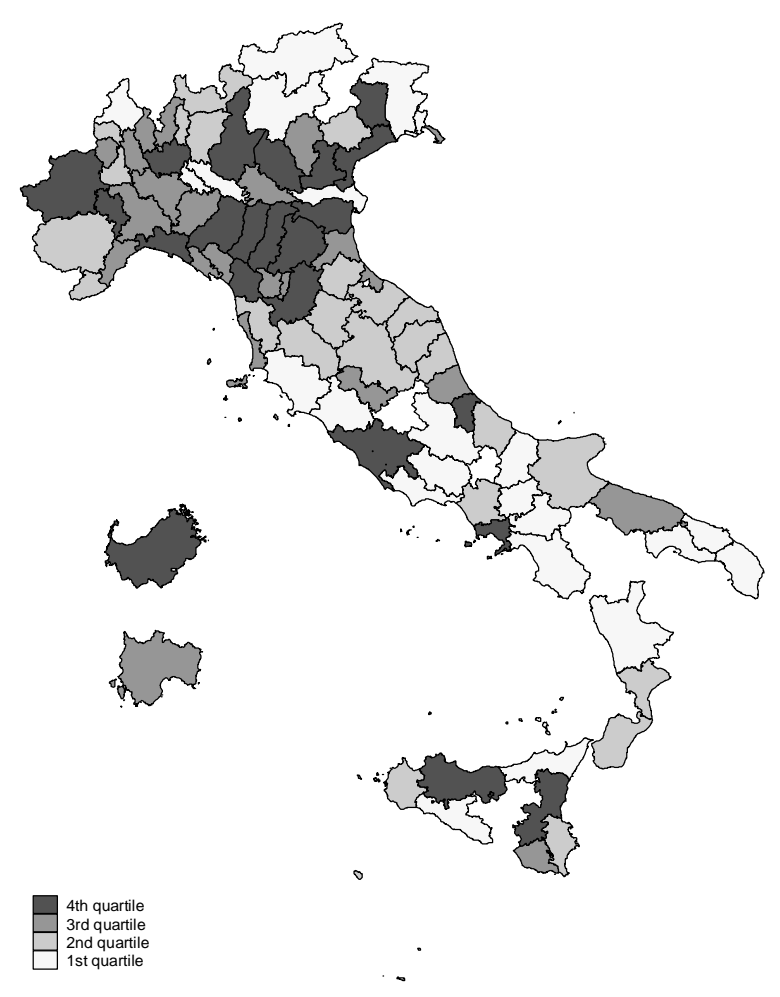

POWER

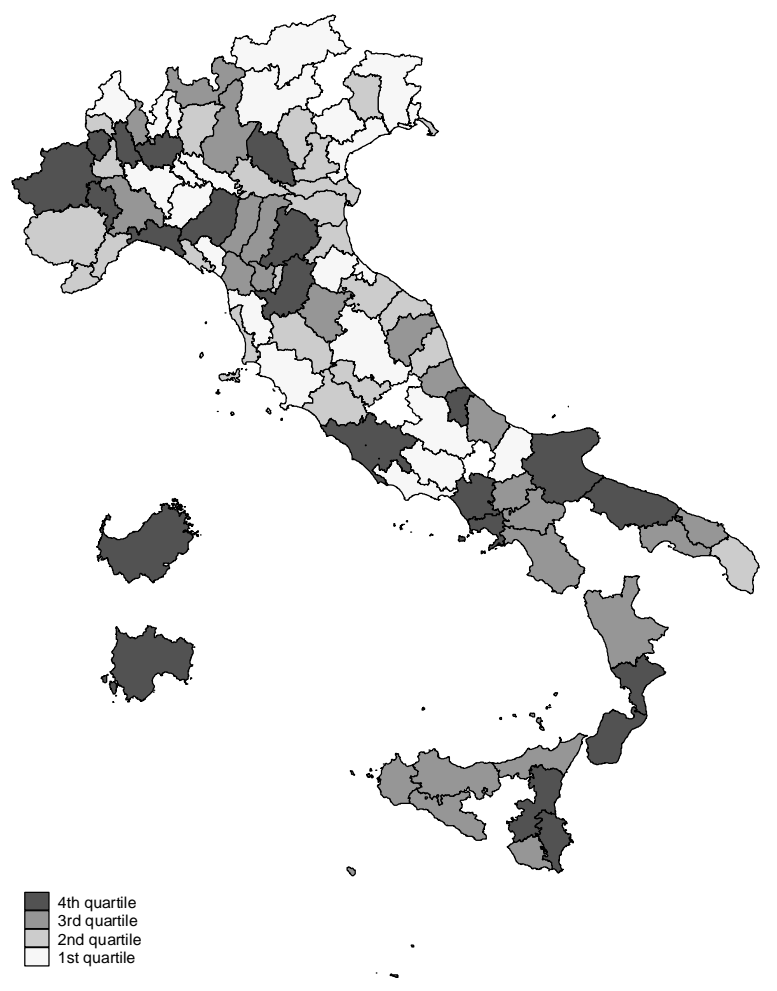




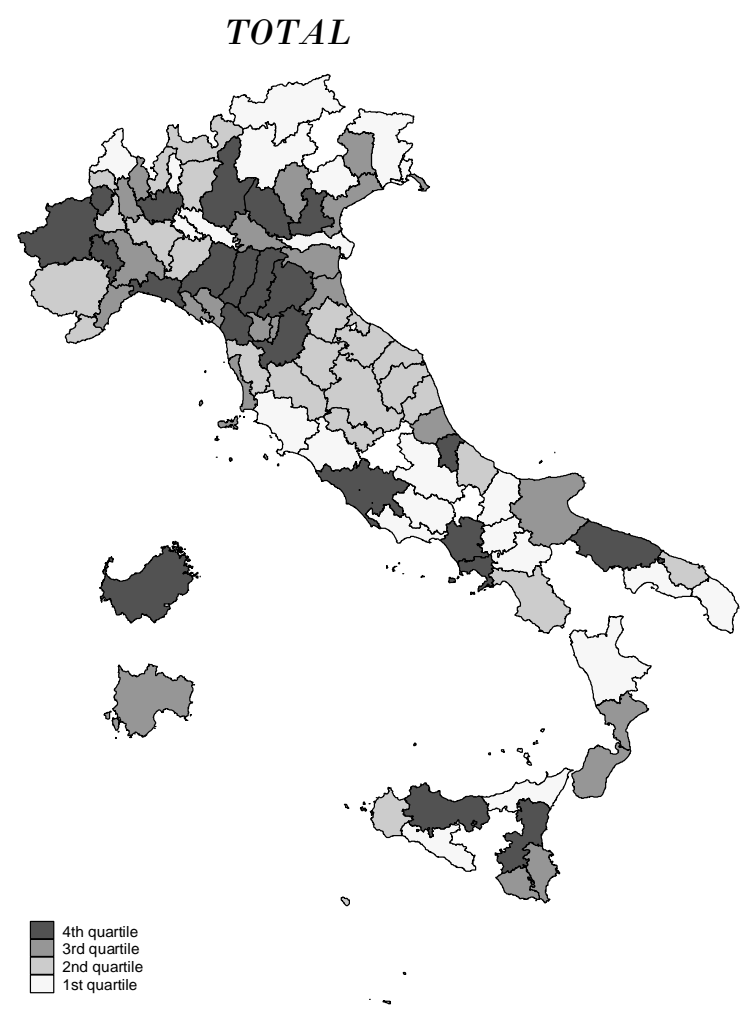

Figure 1 also points to the marked variability across provinces within the two macro-areas, which embrace situations with very low values (white zones) and cases with very high values (dark gray zones). This is particularly evident for the distribution of the ENTERPRISE component in the Centre-North, where it clearly emerges the polarization of the phenomenon in some provinces, including the biggest towns such ad Milan, Turin, Genoa, Bologna and Rome. This helps explain why considering the average values obtained on 83 provinces, i.e., by discarding the estimates with outlier values for ENTERPRISE and POWER shares, the overall size of money laundering decreases significantly (from $6.6 \%$ to $5.1 \%$ in Model 3 ) and also the gap between macro-areas tends to disappear, mainly as a consequence of the lower incidence of the ENTERPRISE component in the Centre-North (which reduces to $4 \%$ ).

\subsection{Robustness analysis}

As a first robustness check for the findings discussed above, we re-estimate Equation [2] using a Tobit Random Effects specification (Tobit RE), in order to explicitly account for unobserved residual heterogeneity across provinces. This model has also the advantage - as compared to a standard panel regression with random effects - to accommodate for the particular distribution of our dependent variable, which is censored at zero and can assume only positive 
values ${ }^{10}$. In particular, we specify the error structure as $\varepsilon_{i t}=u_{i}+e_{i t}$, where $u$ and $e$ are individual effects and the standard disturbance term, respectively.

Table 3: Estimates of cash deposit demand [2]: 91 Italian provinces, 2005-2008 (Tobit regression with Random Effects)

\begin{tabular}{|c|c|}
\hline Regressors a & Model 3 \\
\hline \multicolumn{2}{|c|}{ Money laundering component b } \\
\hline ENTERPRISE & $0.0287^{* *}$ \\
\hline [H1] & $(2.25)$ \\
\hline POWER & $0.0099^{* *}$ \\
\hline$[\mathrm{H} 1]$ & $(2.05)$ \\
\hline \multicolumn{2}{|c|}{ Structural (legal) component ${ }^{\text {b }}$} \\
\hline$Y P C$ & $-0.0061^{* * *}$ \\
\hline [H2] & $(-6.35)$ \\
\hline URATE & $0.2733^{* * *}$ \\
\hline [H3] & $(2.87)$ \\
\hline ELECTRO & $-0.0011^{* * *}$ \\
\hline$[\mathrm{H} 4]$ & $(-3.43)$ \\
\hline \multirow[t]{2}{*}{$I N T$} & 0.0018 \\
\hline & $(0.59)$ \\
\hline \multicolumn{2}{|c|}{ Shadow economy component ${ }^{b}$} \\
\hline$E M P \_A G R$ & $0.4079^{* * *}$ \\
\hline$[\mathrm{H} 5]$ & $(4.51)$ \\
\hline EMP_CON & $0.2614^{* * *}$ \\
\hline$[\mathrm{H} 6]$ & $(2.31)$ \\
\hline \multirow[t]{2}{*}{ COMM_FRAUDS } & $0.0284^{* *}$ \\
\hline & $(2.11)$ \\
\hline Constant & $\begin{array}{l}0.2034^{* * * *} \\
(6.16)\end{array}$ \\
\hline Observations & 364 \\
\hline Wald statistic $\left(\chi^{2}\right)$ & $369.11^{* * *}$ \\
\hline$\sigma_{u}$ & $0.0380^{* * *}$ \\
\hline$\sigma_{e}$ & $0.0189^{* * *}$ \\
\hline
\end{tabular}

a Dependent variable: $I N C A S H$ = value of total cash in-payments on current accounts normalized to the value of total non-cash payments credited to current accounts; z-statistics in round brackets.

b Theoretical hypothesis to which each regressor refers in squared brackets.

***, **, * statistically significant at $1 \%, 5 \%, 10 \%$

${ }^{10}$ See, e.g., Wooldridge (2002). Notice that the theoretical distribution of INCASH is between 0 , if all in-flows on current accounts originate from payment means different from cash, and $\infty$, if all in-flows are made by cash. 
Table 4: Size of money laundering as \% of GDP (mean 2005-2008) - Tobit RE estimates

\begin{tabular}{l|ccc|ccc}
\hline \multirow{2}{*}{ Model 3 } & \multicolumn{3}{|c|}{ 91 provinces a } & \multicolumn{3}{c}{ 83 provinces ${ }^{\mathrm{b}}$} \\
\cline { 2 - 6 } & ITALY & $\begin{array}{c}\text { CENTRE- } \\
\text { NORTH }\end{array}$ & SOUTH & ITALY & $\begin{array}{c}\text { CENTRE- } \\
\text { NORTH }\end{array}$ & SOUTH \\
\hline \hline TOTAL & $7.2 \%$ & $7.7 \%$ & $6.0 \%$ & $5.7 \%$ & $5.5 \%$ & $5.7 \%$ \\
ENTERPRISE & $5.4 \%$ & $6.1 \%$ & $3.6 \%$ & $4.1 \%$ & $4.3 \%$ & $3.4 \%$ \\
POWER & $1.8 \%$ & $1.6 \%$ & $2.4 \%$ & $1.6 \%$ & $1.2 \%$ & $2.3 \%$ \\
Obs. & 364 & 256 & 108 & 336 & 228 & 104 \\
\hline
\end{tabular}

a Average values computed using the whole set of money laundering estimates related to the balanced panel of 91 Italian provinces.

b Before computing average values, we discarded all the provinces showing an outlier estimate of the POWER and/or the ENTERPRISE component in at least one year of the observed period. The 8 outliers were identified using the Hadi $(1992,1994)$ method and mostly correspond to the provinces of the biggest towns in Centre-North Italy.

Coefficient estimates from Model 3 are reported in Table 3, while Table 4 shows the size of money laundering estimated from the same model. The results are consistent with those discussed in the previous section, confirming all our hypotheses H1-H7. More precisely, the average total size of money laundering is around $7 \%$ if computed using the whole set of estimates related to 91 provinces, and reduces to $5.7 \%$ for the restricted sample of 83 provinces which excludes outlier values of ENTERPRISE and POWER. We find again a major role played by ENTERPRISE and a sensible gap between macro-areas, with the provinces in the Centre-North showing a higher value $(7.7 \%$ vs. $6 \%)$ due to the much stronger incidence of the ENTERPRISE component (6.1\% vs. $3.6 \%)$, while those in the South exhibit a relatively higher share for POWER (2.4 vs. 1.6\%). Finally, Figure 2 confirms the marked variability across provinces within each macro-area, as well as the polarization of money laundering in certain provinces, which is particularly evident for the values of ENTERPRISE related to the biggest (and richest) towns in the Centre-North. 
Figure 2: Geographical distribution of money laundering size as a \% of GDP by province (Tobit RE estimates on 91 Italian provinces, mean 2005-2008 - Model 3)

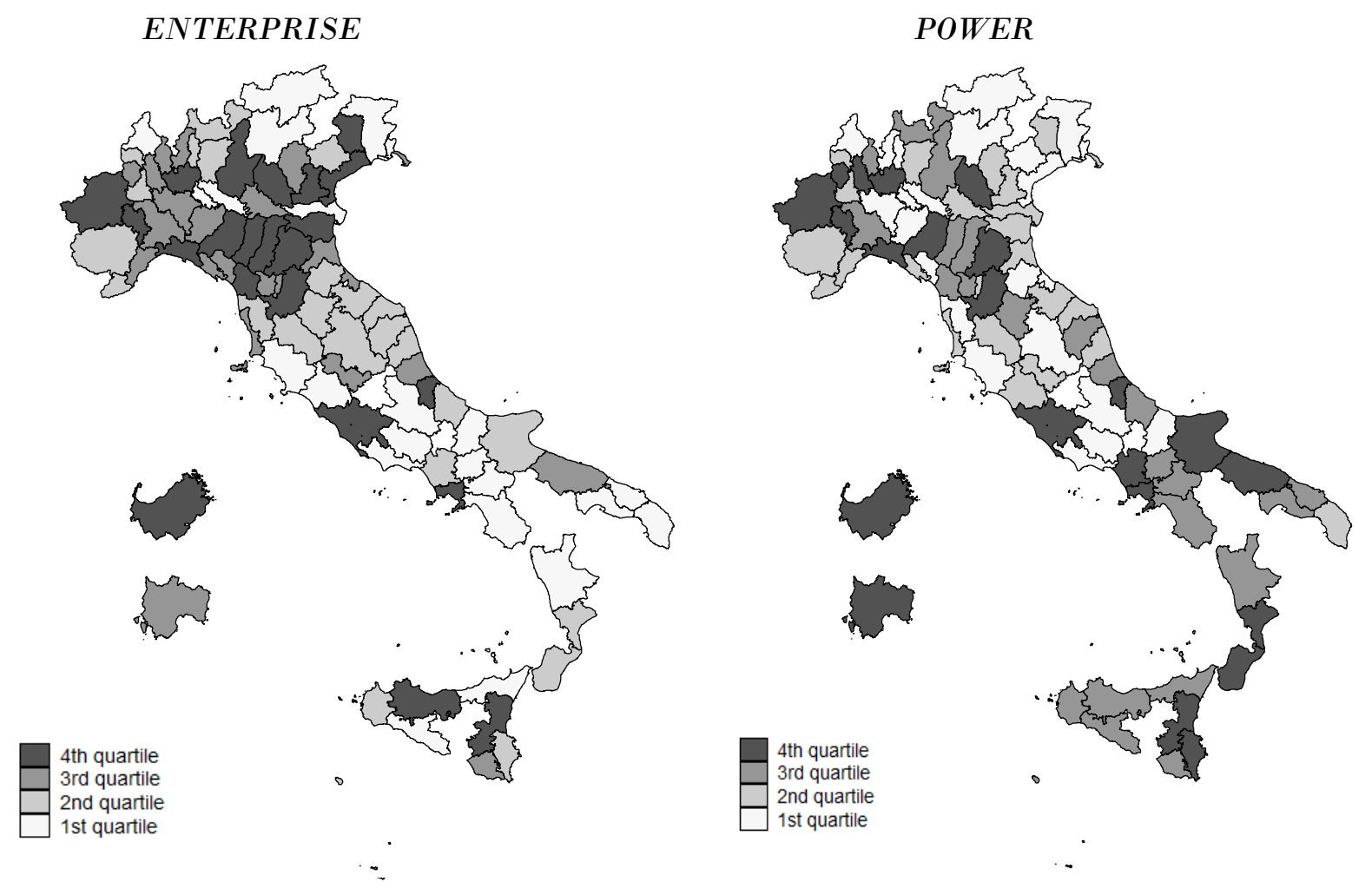

TOTAL

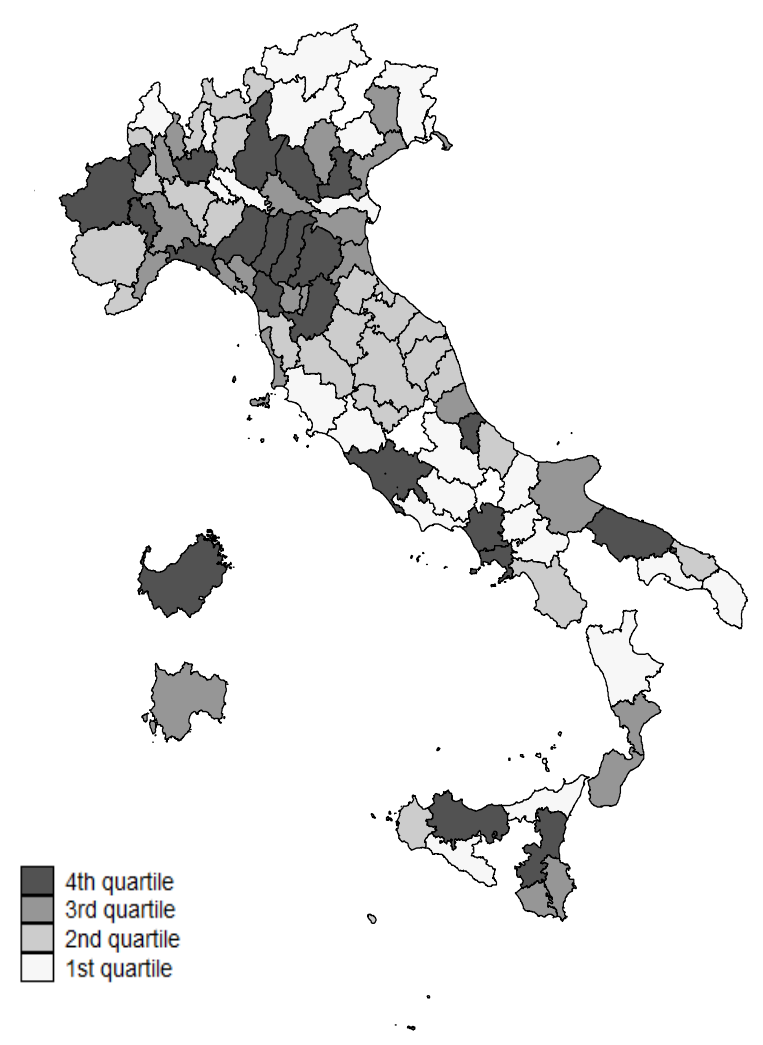


As a second robustness test, we verify whether money laundering estimates are sensible to the exclusion from the sample of some provinces close to the borders, where illegal proceeds instead of being pumped into the Italian banking system - could be illegally exported and deposited in foreign banks. Capital export can clearly bias our dependent variable INCASH, hence our estimates of money laundering. To identify the provinces that could be more affected by the problem, we consider an investigation of the Bank of Italy's Financial Intelligence Unit on the demand of high-denomination banknotes, the ones that could be more easily used to export large amounts of cash. The ranking of the Italian provinces according to the withdrawal of $€ 500$ banknotes per thousand inhabitants in 2009 is hardly surprising. Top listed are some small provinces located near the borders of foreign markets, particularly attractive in the perspective of exporting financial capital and hiding illegal proceeds: Como and Lecco, bordering Switzerland, and Forlì-Cesena and Rimini, bordering the Republic of San Marino ${ }^{11}$.

Table 5 shows the Prais-Winsten regression with PCSE estimates of the demand for cash deposit (Model 3) using reduced samples that excludes the provinces of Como and Lecco (restricted sample 1), the provinces of Forlì-Cesena and Rimini (restricted sample 2), and both groups of border provinces (restricted sample 3). The general goodness of fit of the model is again confirmed: the Wald statistic is always significant at the $1 \%$ level, and the $R^{2}$ is above 0.90. In all the three regressions, coefficients are largely similar to those reported in Table 1, both in terms of statistical significance and magnitude, confirming the robustness of the proposed methodology to sample perturbations accounting for potential limitations in the correct measurement of the amount of cash in-flows deposited on local current accounts. More important, also the estimates of the size of money laundering are confirmed. Table 6 highlights that - compared to the evidence obtained with the full sample of 91 provinces (Table 2, Model 3) - results are slightly higher excluding provinces bordering Switzerland (7.1\%), and slightly lower excluding provinces bordering the Republic of San Marino (5.5\%) and both groups $(6.1 \%)$. Interestingly, in all the three exercises, the observed variation seems to be entirely attributable to the ENTERPRISE component, which suggests a stronger role

\footnotetext{
11 These data are quoted in a newspaper article published by one of the most widely read Italian daily, the Corriere della Sera, on July 24 th 2011 (Gerevini M. and Stringa G., Rischio riciclaggio, l'Italia "taglia" le maxi banconote), and are taken from a reserved report of the Bank of Italy's Financial Intelligence Unit.
} 
of illegal trafficking with respect to extortions in explaining the higher use of highdenomination banknotes in the four provinces.

Table 5: Estimates of cash deposit demand [2]: Exclusion of border provinces with a stronger use of high-denomination banknotes (Prais-Winsten regression with PCSE-Model 3)

\begin{tabular}{|c|c|c|c|}
\hline Regressors $^{\text {a }}$ & Restricted sample $1^{b}$ & Restricted sample 2 b & Restricted sample $3^{b}$ \\
\hline \multicolumn{4}{|c|}{ Money laundering component ${ }^{\mathrm{c}}$} \\
\hline ENTERPRISE & $0.0291 * * *$ & $0.0208^{*}$ & $0.0235^{* *}$ \\
\hline$[\mathrm{H} 1]$ & $(3.28)$ & $(1.64)$ & $(1.99)$ \\
\hline POWER & $0.0088 *$ & $0.0085^{*}$ & $0.0085^{*}$ \\
\hline$[\mathrm{H} 1]$ & $(1.80)$ & $(1.64)$ & $(1.64)$ \\
\hline \multicolumn{4}{|c|}{ Structural (legal)component ${ }^{\mathrm{c}}$} \\
\hline$Y P C$ & $-0.0043^{* * *}$ & $-0.0045 * * *$ & $-0.0045 * * *$ \\
\hline [H2] & $(-3.07)$ & $(-3.06)$ & $(-3.07)$ \\
\hline URATE & $0.3860^{* * *}$ & $0.4017 * * *$ & $0.4037 * * *$ \\
\hline$[\mathrm{H} 3]$ & $(2.60)$ & $(2.74)$ & $(2.73)$ \\
\hline ELECTRO & $-0.0015^{* * *}$ & $-0.0014^{* * *}$ & $-0.0014^{* * *}$ \\
\hline$[\mathrm{H} 4]$ & $(-6.40)$ & $(-5.16)$ & $(-5.51)$ \\
\hline \multirow[t]{2}{*}{$I N T$} & -0.0015 & -0.0014 & -0.0010 \\
\hline & $(-0.60)$ & $(-0.53)$ & $(-0.40)$ \\
\hline \multicolumn{4}{|c|}{ Shadow economy component ${ }^{\text {c }}$} \\
\hline$E M P \_A G R$ & $0.5222 * * *$ & $0.5078^{* * *}$ & $0.5195^{* * *}$ \\
\hline$[\mathrm{H} 5]$ & $(4.73)$ & $(5.03)$ & $(4.81)$ \\
\hline EMP_CON & $0.3239^{* *}$ & $0.3257^{* *}$ & $0.3173^{* *}$ \\
\hline$[\mathrm{H} 5]$ & $(2.16)$ & $(2.22)$ & $(2.15)$ \\
\hline COMM_FRAUDS & $0.0609 * * *$ & $0.0605 * * *$ & $0.0609 * * *$ \\
\hline$[\mathrm{H} 6]$ & $(5.05)$ & $(5.35)$ & $(5.22)$ \\
\hline Constant & $\begin{array}{c}0.1371^{* * *} \\
(2.54)\end{array}$ & $\begin{array}{c}0.1468^{* * *} \\
(2.68)\end{array}$ & $\begin{array}{c}0.1431^{* * *} \\
(2.60)\end{array}$ \\
\hline Observations & 356 & 356 & 348 \\
\hline Wald statistic $\left(\chi^{2}\right)$ & $6237.74^{* * *}$ & $4934.86^{* * *}$ & $5433.72^{* * *}$ \\
\hline $\mathrm{R}^{2}$ & 0.92 & 0.91 & 0.91 \\
\hline
\end{tabular}

a Dependent variable: INCASH = value of total cash in-payments on current accounts normalized to the value of total non-cash payments credited to current accounts; z-statistics in round brackets.

${ }^{\mathrm{b}}$ Restricted sample 1 excludes the two provinces of Como and Lecco that border with Switzerland. Restricted sample 2 excludes the two provinces of Forlì-Cesena and Rimini that border with the Republic of San Marino. Restricted sample 3 excludes both groups of border provinces.

c Theoretical hypothesis to which each regressor refers in squared brackets.

$* * *, * *, *$ : statistically significant at $1 \%, 5 \%, 10 \%$. 
As for the differences in the direction of the bias between the provinces close to Switzerland and those bordering the Republic of San Marino, a likely interpretation is in the degree of integration with the Italian system of payments, substantially higher for banks in the Republic of San Marino with respect to Swiss banks ${ }^{12}$.

Table 6: Size of money laundering as \% of GDP (mean 2005-2008) - PCSE estimates relative to restricted samples excluding border provinces with a stronger use of high-denomination banknotes

\begin{tabular}{|c|c|c|c|c|c|c|c|c|c|}
\hline \multirow{2}{*}{ Model 3} & \multicolumn{3}{|c|}{ Restricted sample $1^{\text {a }}$} & \multicolumn{3}{|c|}{ Restricted sample $2^{\text {b }}$} & \multicolumn{3}{|c|}{ Restricted sample $3^{c}$} \\
\hline & ITALY & $\begin{array}{c}\text { CENTRE- } \\
\text { NORTH }\end{array}$ & SOUTH & ITALY & $\begin{array}{c}\text { CENTRE- } \\
\text { NORTH }\end{array}$ & SOUTH & ITALY & $\begin{array}{c}\text { CENTRE- } \\
\text { NORTH }\end{array}$ & SOUTH \\
\hline TOTAL & $7.1 \%$ & $7.7 \%$ & $5.8 \%$ & $5.5 \%$ & $5.9 \%$ & $4.7 \%$ & $6.1 \%$ & $6.6 \%$ & $5.0 \%$ \\
\hline ENTERPRISE & $5.5 \%$ & $6.3 \%$ & $3.6 \%$ & $3.9 \%$ & $4.5 \%$ & $2.6 \%$ & $4.5 \%$ & $5.2 \%$ & $2.9 \%$ \\
\hline POWER & $1.6 \%$ & $1.4 \%$ & $2.1 \%$ & $1.6 \%$ & $1.4 \%$ & $2.1 \%$ & $1.6 \%$ & $1.4 \%$ & $2.1 \%$ \\
\hline Obs. & 356 & 248 & 108 & 356 & 248 & 108 & 348 & 240 & 108 \\
\hline
\end{tabular}

a 89 provinces: Como and Lecco excluded from the estimation.

b 89 provinces: Forlì-Cesena and Rimini excluded from the estimation.

c 87 provinces: Como, Lecco, Forlì-Cesena and Rimini excluded from the estimation.

\section{Summary and policy conclusions}

In this paper we provide a first attempt to estimate the size of money laundering using an approach based on observed cash in-flows credited on (banking and postal) current accounts, considering a panel of 91 Italian provinces over the period 2005 to 2008. Our econometric results confirm that the demand for cash deposits is driven by three different components: (1) a money laundering component: the diffusion of both illegal traffics and extortion activities prove to be important drivers of cash in-flows; (2) a structural (legal) component: the average per capita income and the diffusion of electronic payments are negatively associated with cash in-flows, while unemployment rate shows a positive correlation; (3) a component stemming

\footnotetext{
12 This last consideration seems to be consistent with the risk analysis reported in the Annual Report of the Bank of Italy's Financial Intelligence Unit for 2009 (p. 5, English version): the Unit carried out several inspections at local branches both because of anomalous financial flows between banks located in Italy and San Marino, and because of the existence of special agreements between Italian operators and foreign counterparts for the exchange of euro banknotes (p. 28, Italian version). Accordingly, if we drop the provinces close to San Marino, we likely reduce the average level of money laundering activities, since we partly leave out the phenomenon, while in the case of provinces bordering Switzerland there is a possible undetected export of cash, which originates an incomplete measurement of the true cash in-flows.
} 
from the underground economy: the presence of irregular workers and of commercial tax frauds is positively correlated with cash in-flows.

Starting from these findings, the estimated relative size of money laundering at the national level ranges from $6.6 \%$ of GDP to around $8 \%$. Splitting the provinces between macro-areas, we find that the share of "dirty money" on GDP is $7.1 \%$ in the Centre-North against $5.4 \%$ in the South. When we consider ENTERPRISE and POWER separately, our results indicate that the sources of "dirty money" differ across areas: proceedings to be laundered coming from illegal traffics are about 1.7 times higher in Centre-Northern provinces than in Southern ones $(5.7 \%$ versus $3.3 \%)$; the inverse is true for proceedings from extortions, for which the share in the South is 1.5 times the value of the Centre-North (2.1\% versus $1.4 \%)$. This evidence is coherent with the presence of a direct control of local territories in the South by the big criminal organizations (Mafia, Camorra, 'Ndrangheta, and Sacra Corona Unita), and the ability of these criminal organizations to exploit richer retail markets in the CentreNorth.

What type of policy conclusions can we draw from these results? The amount of money laundering in the Italian provinces is sizeable and this should be one of major policy concern for governments, since Italy is not among the non-cooperative countries and territories identified by the FATF, and it is certainly not a tax haven allowing to set up anonymous companies. Hence, it is likely that criminal organizations are able to circumvent the KYC rule, even in the presence of a strict regulation. Our approach here suggests that criminal organizations provides a sizeable amount of cash proceeds which are whitewashed via the regulated financial and banking system. Hence, an alternative strategy to fight this crime with respect to transparency rules would be to reduce the attractiveness of untraceable means of payments. In this perspective, limiting the use of cash in transactions would not only be beneficial to improve the efficiency of the payments system, but also to combat crime. 


\section{REFERENCES}

Alexeev, M., Janeba, E., and Osborne S. (2004), "Taxation and Evasion in the Presence of Extortion by Organized Crime", Journal of Comparative Economics, 32, 375-387.

Ardizzi, G., Petraglia, C., Piacenza, M., and Turati, G. (2013), "Measuring the Underground Economy with the Currency Demand Approach: A Reinterpretation of the Methodology, with an Application to Italy", Review of Income and Wealth, forthcoming.

Argentiero, A., Bagella, M. and Busato, F. (2008), "Money Laundering in a Two Sector Model: Using Theory for Measurement", European Journal of Law and Economics, 26(3), 341-359.

Bank of Italy - Financial Intelligence Unit (2010), Annual Report on 2009.

Barone, R., Masciandaro, D. (2011), “Organized crime, money laundering and legal economy: theory and simulations", European Journal of Law Economics, 32(1), 115-142

Beck, N., and Katz., J. N. (1995), “What to Do (and Not to Do) with Time-Series CrossSection Data", American Political Science Review, 89, 634-647.

Block, A. (1980), East Side - West Side. Organizing Crime in New York 1930-1950, Cardiff: University College Cardiff Press.

Brandolini, A., Cannari, L., D'Alessio, G. and Faiella, I. (2004), "Household Wealth Distribution in Italy in the 1990s", Bank of Italy, Discussion paper, No. 530, December 2004.

Buehn, A. and Schneider, F. (2012), "Shadow Economies around the World: Novel Insights, Accepted Knowledge, and New Estimates", International Tax and Public Finance, 19, 139-171.

Cameron, A. C. and Trivedi, P. K. (2005), Microeconometrics: Methods and Applications, New York: Cambridge University Press.

Capasso, C., and Jappelli, T. (2011), "Financial Development and the Underground Economy", University of Naples Federico II, CSEF Working Paper, No. 298, November 2011 .

Capgemini and Royal Bank of Scotland (2011), World Payments Report, European Financial Management \& Marketing Association.

Drehmann, M. and Goodhart, C.A.E. (2000), "Is Cash Becoming Technologically Outmoded? Or Does it Remain Necessary to Facilitate Bad Behaviour? An Empirical Investigation into the Determinants of Cash Holdings", Financial Markets Group Research Centre, Discussion Paper, No. 358, LSE.

European Central Bank (2008), Economic Bulletin, special edition, May. 
Federal Bureau of Investigation (2011), Financial Crimes Report to the Public, available at http://www.fbi.gov/stats-services/publications/financial-crimes-report-20102011/financial-crimes-report-2010-2011\#Asset.

Findley M., Nielson D., and Sharman J., (2012), "Global Shell Games: Testing Money Launderers' and Terrorist Financiers' Access to Shell Companies", Political Economy and Development Lab, Brigham University.

Gambetta, D. (1993), The Sicilian Mafia. The Business of Private Protection, Cambridge: Harvard University Press.

Goodhart, C. and Krueger, M. (2001), "The Impact of Technology on Cash Usage", Financial Markets Group Research Centre, Discussion Paper, No. 374, LSE.

Greene, W. (2000), Econometric Analysis, Upper Saddle River, NJ: Prentice-Hall.

Hadi, A.S. (1992), "Identifying Multiple Outliers in Multivariate Data", Journal of the Royal Statistical Society, Series B, 54, 761-771.

Hadi, A.S. (1994), "A Modification of a Method for the Detection of Outliers in Multivariate Samples", Journal of the Royal Statistical Society, Series B, 56, 393-396.

Hines, J.R. (2010), “Treasure Islands", Journal of Economic Perspectives, 24(4), 103-126.

Hoechle, D. (2007), "Robust Standard Errors for Panel Regressions with Cross-Sectional Dependence", The Stata Journal, 7(3), 281-312.

International Monetary Fund (2001), Financial System Abuse, Financial Crime and Money Laundering, Washington.

Istat (2010), "La misura dell'economia sommersa secondo le statistiche ufficiali. Anni 20002008", Conti Nazionali - Statistiche in Breve, Istituto Nazionale di Statistica, Rome.

Johnson, S., Kaufmann, D., McMillan, J. and Woodruff, C. (2000), "Why Do Firms Hide? Bribes and Unofficial Activity after Communism", Journal of Public Economics, 76(3), 495-520.

Masciandaro, D., Takáts, E., and Unger B. (2007), Black Finance. The Economics of Money Laundering, Cheltenham, UK: Edward Elgar.

OECD (2002), Measuring the Non-Observed Economy - A Handbook, Paris.

Payments Council (2010), The future for cash in the UK, Strategic Cash Group, London.

Pesaran, M.H. (2004), "General Diagnostic Tests for Cross Section Dependence in Panels", Cambridge Working Papers in Economics, No. 0435, Faculty of Economics, University of Cambridge.

Prais, S.J. and Winsten, C.B. (1954), “Trend Estimators and Serial Correlation", Cowles Commission Discussion Paper, No. 383 , Chicago.

Schneider, F. (2009), "The Shadow Economy in Europe. Using Payment Systems to Combat the Shadow Economy", A.T. Kearney Research Report, September. 
Schneider, F. (2010), "Turnover of Organized Crime and Money Laundering: Some Preliminary Empirical Findings", Public Choice, 144(3), 473-486.

Schneider, F. (2011), Handbook on the Shadow Economy, Cheltenham (UK): Edward Elgar.

Schneider, F. and Enste D.H. (2000), "Shadow Economies: Size, Causes and Consequences", Journal of Economic Literature, 38(1), 77-114.

Schneider, F. and Windischbauer, U. (2008), "Money Laundering: Some Facts", European Journal of Law and Economics, 26(3), 387-404.

Sharman, J.C. (2010), "Shopping for Anonymous Shell Companies: An Audit Study of Anonymity and Crime in the International Financial System", Journal of Economic Perspectives, 24(4), 127-140.

Tanzi, V. (1980), "The Underground Economy in the United States: Estimates and Implications", Banca Nazionale del Lavoro Quarterly Review, 135(4), 427-453.

Tanzi, V. (1983), “The Underground Economy in the United States: Annual Estimates 19301980", IMF Staff Papers, 30(2), 283-305.

Tanzi, V. (1997), “Macroeconomic Implications of Money Laundering," in E.U. Savona (Ed.), Responding to Money Laundering, International Perspectives, 91-104. Amsterdam: Harwood Academic Publishers.

Torgler, B. and Schneider F. (2009) "The Impact of Tax Morale and Institutional Quality on the Shadow Economy", Journal of Economic Psychology, 30(2), 228-245.

Transcrime (2008), Study on Extortion Racketeering - The Need for an Instrument to Combat Activities of Organized Crime, Research Centre on Transnational Crime, University of Trento and Catholic University of Milan, final report.

Unger, B. (2007), The Scale and Impact of Money Laundering, Cheltenham, UK: Edward Elgar.

Unger, B. (2009), "Money Laundering - A Newly Emerging Topic on the International Agenda", Review of Law and Economics, 807-819.

United Nations Office on Drugs and Crime (2011), Estimating illicit financial flows resulting from drug trafficking and other transnational organized crimes, Wien.

Wagstaff, A., van Doorslaer, E. and Watanabe, N. (2003), "On decomposing the causes of health sector inequalities with an application to malnutrition inequalities in Vietnam", Journal of Econometrics, 112(1), 207-223.

Walker, J. (1999), "How Big is Global Money Laundering?", Journal of Money Laundering Control, 3(1), 25-37.

Wooldridge, J.M. (2002), Econometric Analysis of Cross Section and Panel Data, Cambridge, MA: MIT Press.

World Bank (2005), International Migration, Remittances, and the Brain Drain, M. Schiff and C. Ozden (eds.), Washington, D.C. 
Appendix. Definition, descriptive statistics and contribution of the different variables included in the equation [1] of cash deposit demand

This study uses a balanced panel of Italian provinces over the period 2005-2008. The dataset merges information of four different sources: Bank of Italy (BdI), Guardia di Finanza (the Italian Tax Police, GdF), Istat (the National Institute of Statistics), and Eurostat (the European Institute of Statistics). All monetary variables are provided by BdI. Data on the provincial GDP and unemployment rate are provided by Eurostat and Istat, respectively. The variables used as proxies for the diffusion of commercial tax frauds and irregular work are computed on the basis of information provided by GdF and Istat. Finally, the indexes of crime diffusion are computed using data on criminal offences available from Istat website http://giustiziaincifre.istat.it. Complete information for all the variables are available for 91 Italian provinces (out of a total of 103).

Table A1. Definition of variables and data source

\begin{tabular}{|c|c|c|}
\hline & Definition & Source \\
\hline \multicolumn{3}{|l|}{ DEPENDENT variable } \\
\hline$I N C A S H$ & $\begin{array}{l}\text { Ratio of the value of total cash in-flows to the value of total } \\
\text { non-cash in-flows on current (bank and postal) accounts }\end{array}$ & BdI \\
\hline \multicolumn{3}{|c|}{ MONEY LAUNDERING variables } \\
\hline ENTERPRISE & $\begin{array}{l}\text { Number of crimes from drug dealing, prostitution and receiving } \\
\text { stolen within the province (divided by its sample mean value and } \\
\text { weighted by a GDP concentration index) }\end{array}$ & Istat and Eurostat \\
\hline POWER & $\begin{array}{l}\text { Number of crimes from extortion within the province (divided by } \\
\text { its sample mean value and weighted by a GDP concentration } \\
\text { index) }\end{array}$ & Istat and Eurostat \\
\hline \multicolumn{3}{|c|}{ STRUCTURAL (LEGAL) variables } \\
\hline$Y P C$ & Per capita provincial GDP & Eurostat \\
\hline URATE & Provincial unemployment rate & Istat \\
\hline ELECTRO & $\begin{array}{l}\text { Ratio of the value of transactions settled by electronic payments } \\
\text { to the total number of current accounts }\end{array}$ & BdI \\
\hline$I N T$ & Rate of interest on current accounts & BdI \\
\hline \multicolumn{3}{|c|}{ SHADOW ECONOMY variables } \\
\hline$E M P \_A G R$ & Share of employment in agriculture (proxy for irregular work) & Istat \\
\hline$E M P \_C O N$ & Share of employment in constructions (proxy for irregular work) & Istat \\
\hline COMM_FRAUDS & $\begin{array}{l}\text { Ratio of the number of detected tax frauds on cash registers and } \\
\text { commercial receipts within the province to the number of } \\
\text { existing POS (divided by its sample mean value and weighted } \\
\text { by a GDP concentration index) }\end{array}$ & GdF, BdI and Eurostat \\
\hline
\end{tabular}


Table A2. Descriptive statistics

\begin{tabular}{|c|c|c|c|c|c|c|}
\hline \multirow[b]{2}{*}{ Variable } & \multirow[b]{2}{*}{ Mean } & \multicolumn{3}{|c|}{ Standard Deviation } & \multirow[b]{2}{*}{ Min } & \multirow[b]{2}{*}{$\operatorname{Max}$} \\
\hline & & Total & Between & Within & & \\
\hline \multicolumn{7}{|c|}{ ITALY a } \\
\hline INCASH & 0.143 & 0.088 & 0.086 & 0.017 & 0.014 & 0.491 \\
\hline ENTERPRISE & 0.798 & 0.278 & 0.274 & 0.051 & 0.277 & 1.992 \\
\hline POWER & 1.010 & 0.789 & 0.773 & 0.175 & 0.171 & 3.859 \\
\hline$Y P C\left(10^{3} €\right)$ & 24.910 & 5.959 & 5.901 & 0.987 & 12.346 & 39.082 \\
\hline$U R A T E$ & 0.066 & 0.039 & 0.038 & 0.010 & 0.019 & 0.192 \\
\hline ELECTRO $\left(10^{4} €\right)$ & 9.001 & 6.584 & 6.033 & 2.693 & 1.974 & 65.717 \\
\hline$I N T$ & 1.247 & 0.488 & 0.265 & 0.410 & 0.472 & 2.909 \\
\hline$E M P \_A G R$ & 0.050 & 0.038 & 0.037 & 0.009 & 0.000 & 0.228 \\
\hline EMP_CON & 0.087 & 0.019 & 0.017 & 0.008 & 0.032 & 0.144 \\
\hline COMM_FRAUDS & 0.204 & 0.215 & 0.207 & 0.063 & 0.001 & 1.233 \\
\hline \multicolumn{7}{|c|}{ CENTRE-NORTH b } \\
\hline INCASH & 0.102 & 0.052 & 0.051 & 0.011 & 0.014 & 0.293 \\
\hline ENTERPRISE & 0.742 & 0.246 & 0.244 & 0.040 & 0.277 & 1.631 \\
\hline POWER & 0.605 & 0.218 & 0.187 & 0.114 & 0.171 & 1.291 \\
\hline$Y P C\left(10^{3} €\right)$ & 28.232 & 3.350 & 3.181 & 1.107 & 20.612 & 39.082 \\
\hline$U R A T E$ & 0.045 & 0.016 & 0.015 & 0.006 & 0.019 & 0.102 \\
\hline $\operatorname{ELECTRO~}\left(10^{4} €\right)$ & 9.903 & 7.572 & 6.917 & 3.170 & 1.974 & 65.717 \\
\hline$I N T$ & 1.299 & 0.504 & 0.261 & 0.432 & 0.472 & 2.909 \\
\hline$E M P \_A G R$ & 0.038 & 0.027 & 0.027 & 0.007 & 0.000 & 0.128 \\
\hline$E M P \_C O N$ & 0.083 & 0.018 & 0.017 & 0.008 & 0.032 & 0.144 \\
\hline COMM_FRAUDS & 0.149 & 0.186 & 0.178 & 0.059 & 0.001 & 1.233 \\
\hline \multicolumn{7}{|c|}{ SOUTH c } \\
\hline INCASH & 0.240 & 0.078 & 0.074 & 0.027 & 0.084 & 0.491 \\
\hline ENTERPRISE & 0.931 & 0.302 & 0.788 & 0.271 & 0.458 & 1.992 \\
\hline POWER & 1.970 & 0.823 & 0.298 & 0.070 & 0.550 & 3.859 \\
\hline$Y P C\left(10^{3} €\right)$ & 17.034 & 2.163 & 2.101 & 0.621 & 12.346 & 22.181 \\
\hline$U R A T E$ & 0.116 & 0.032 & 0.028 & 0.016 & 0.053 & 0.192 \\
\hline $\operatorname{ELECTRO~}\left(10^{4} €\right)$ & 6.860 & 1.960 & 1.811 & 0.808 & 3.124 & 11.190 \\
\hline$I N T$ & 1.123 & 0.424 & 0.235 & 0.355 & 0.475 & 2.480 \\
\hline$E M P_{-} A G R$ & 0.079 & 0.042 & 0.042 & 0.011 & 0.000 & 0.228 \\
\hline EMP_CON & 0.098 & 0.015 & 0.012 & 0.009 & 0.064 & 0.125 \\
\hline COMM_FRAUDS & 0.335 & 0.224 & 0.215 & 0.072 & 0.037 & 0.983 \\
\hline
\end{tabular}

a Figures based on a balanced panel of 91 provinces over years 2005-2008 (364 observations).

b Figures based on a balanced panel of 64 provinces over years 2005-2008 (256 observations).

c Figures based on a balanced panel of 27 provinces over years 2005-2008 (108 observations). 
Table A3. Contribution of the variables included in the equation [1] of cash deposit demand (PCSE estimates on 91 Italian provinces, mean 2005-2008 - Model 3)

\begin{tabular}{lccc}
\hline & ITALY & CENTRE-NORTH & SOUTH \\
\hline \hline Observed cash deposits (\% GDP) & 100 & 100 & 100 \\
YPC & -115 & -160 & -34 \\
ELECTRO & -20 & -28 & -5 \\
INT & -2 & -3 & -1 \\
Constant & 135 & 176 & 64 \\
EMP_CON & 26 & 33 & 14 \\
ENTERPRISE & 21 & 26 & 12 \\
EMP_AGR & 20 & 21 & 17 \\
URATE & 20 & 20 & 19 \\
COMM_FRAUDS & 9 & 9 & 8 \\
POWER & 7 & 6 & 7 \\
\hline \hline Observations & 364 & 256 & 108 \\
\hline
\end{tabular}

--- positive contribution

--- negative contribution 
Figure A1. Contribution of the variables included in the equation [1] of cash deposit demand (PCSE estimates on 91 Italian provinces, mean 2005-2008 - Model 3)

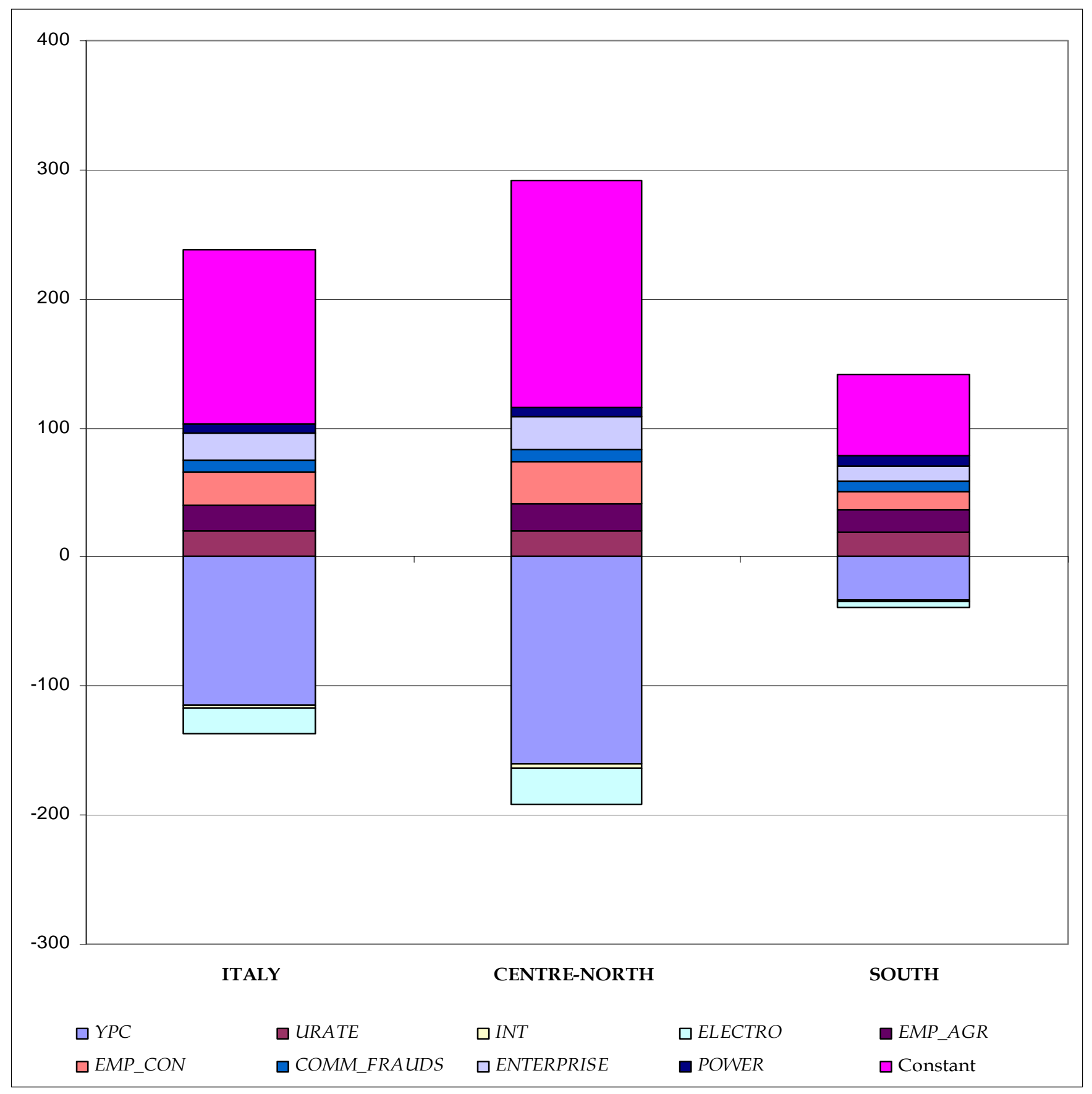




\section{DEPARTMENT OF ECONOMICS AND STATISTICS UNIVERSITY OF TORINO}

Corso Unione Sovietica 218 bis - 10134 Torino (ITALY) Web page: http://esomas.econ.unito.it/ 